\title{
Nematicidal and larvicidal activities of the essential oils from aerial parts of Pectis oligocephala and Pectis apodocephala Baker
}

\author{
MARIA ROSE JANE R. ALbUQUERQUE ${ }^{1}$, SONIA MARIA O. COSTA $^{2}$, PAUlO N. BANDEIRA ${ }^{2}$, \\ GILVANDETE MARIA P. SANTIAGO ${ }^{3}$, MANOEL ANDRADE-NETO ${ }^{1}$, EDILBERTO R. SILVEIRA ${ }^{1}$ \\ and OTILIA D.L. PESSOA ${ }^{1}$ \\ ${ }^{1}$ Departamento de Química Orgânica e Inorgânica, Centro de Ciências, Universidade Federal do Ceará, Campus do Picí \\ Caixa Postal 12200, 60021-970 Fortaleza, CE, Brasil \\ ${ }^{2}$ Coordenação de Química/Biologia, Universidade Estadual Vale do Acaraú, Campus Betânia \\ Caixa Postal D-3, 62040-370 Sobral, CE, Brasil \\ ${ }^{3}$ Departamento de Farmácia, Faculdade de Farmácia, Odontologia e Enfermagem, Universidade Federal do Ceará, \\ Rua Capitão Francisco Pedro, 1210, Rodolfo Teófilo, 60430-370 Fortaleza, CE, Brasil \\ Manuscript received on October 19, 2005; accepted for publication on August 15, 2006; \\ presented by RAIMUNDO BRAZ FILHO
}

\begin{abstract}
The chemical composition of the essential oils from aerial parts of Pectis apodocephala and Pectis oligocephala were analyzed by GC-MS. The essential oils of these species were predominantly constituted by monoterpenes. Geranial (42.9-44.5\%), neral (32.2-34.2\%) and $\alpha$-pinene (10.7-11.4\%) were the main constituents in the oil of P. apodocephala, while $p$-cymene (50.3-70.9\%) and thymol (24.4-44.7\%), were the prevalent compounds in the oil of P. oligocephala. The essential oils were tested against the root knot nematode Meloidogyne incognita and Aedes aegypti larvae survival. The results obtained show that both essential oils exhibited significant activity and could be considered as potent natural namaticidal and larvicidal agents.
\end{abstract}

Key words: Pectis apodocephala, Pectis oligocephala, essential oil, nematicidal activity, larvicidal activity.

\section{INTRODUCTION}

Essential oils from different plant sources have demonstrated several biological activities, including antibacterial (Iacobellis et al. 2005), insecticidal (Araújo et al. 2003), larvicidal (Albuquerque et al. 2004a), acaricidal (Kim et al. 2004), nematicidal (Duschatzky et al. 2004) and antifungal (Wang et al. 2005). As a consequence, this vast arsenal of bioactive compounds has attracted significant and crescent attention of researchers in recent years. Nematodes are tiny worms, some of them are parasites to plants, and can play an important role in the predisposition of the host plant to the invasion by secondary pathogens (Jayasinghe et al. 2003). Plants

Correspondence to: Dra. Otília Deusdênia Loiola Pessoa E-mail: opessoa@ufc.br attacked by nematodes show retarded growth and development, as well as loss in the quality and quantity of the harvest product. The nematode Meloidogyne incognita is a widespread nematode found in several important agronomical cultures of Brazil.

Innumerous human diseases such as malaria, filariasis, dengue fever, yellow fever and several viral diseases are transmitted by mosquitoes (Venkatachalam and Jebanesan 2001), being the Aedes aegypti one of the most hazardous because it is the vector for yellow fever and dengue hemorrhagic fever, besides to be responsible for some allergic response such as urticaria and angioedema (Cheng et al. 2003). The synthetic pesticides have been generally used with success for the eradication of nematode $M$. incognita and A. aegypti larvae. Nevertheless, the continuous and indiscriminate use of synthetic in- 
secticides has also induced undesirable effects including toxicity to non-target organisms and environmental pollution problems. Since essential oils constitute a rich source of bioactive compounds, they may be considered as an useful alternative strategy to the currently available insecticidal agents in the use for controlling both M. incognita and A. aegypti.

As part of a continuous research program on aromatic plants from Northeast Brazil, we have investigated the volatile composition of the essential oils of several plants from the Asteraceae family (Albuquerque et al. 2001, 2003, 2004a, b). The genus Pectis is constituted by approximately 76 neotropical species. Despite the etnobotanical uses of some of them, this genus has been the subject of scant phytochemical and biological studies. In the flora of Northeast Brazil, the genus is represented by five species, including Pectis apodocephala and Pectis oligocephala, whose essential oils we have previously investigated (Craveiro et al. 1986, Albuquerque et al. 2003). The present work reports the reinvestigation of the essential oils from aerial parts of $P$. apodocephala and P. oligocephala, as well as their nematicidal and larvicidal effects against the nematode $M$. incognita and A. aegypti larvae.

\section{MATERIALS AND METHODS}

\section{Plant Material}

Both P. apodocephala and P. oligocephala, in the flowering stage were collected in May 2000 and June 2003, in Sobral County, State of Ceará, Northeast Brazil. Voucher specimens (\#29441 and \#29453) were deposited at the Herbário Prisco Bezerra (EAC) of the Departamento de Biologia, Universidade Federal do Ceará, Brazil.

\section{EXTRACTION OF THE ESSENTIAL OILS}

Samples of fresh aerial parts of both species were subjected to hydrodistillation for 2 hours in a Clevenger-type apparatus. The isolated oils were subsequently dried over anhydrous sodium sulfate and stored under refrigeration until analyzed and tested. The oil yields (w/w on fresh weight basis) for P. apodocephala were 0.20 and $0.12 \%$, while the oil yields for P. oligocephala were 0.40 and $0.18 \%$, respectively.

\section{ANALYSIS OF THE ESSENTIAL OILS}

The volatile components from aerial parts of P. apodocephala and P. oligocephala (Table I), were analyzed by GC-MS on a Hewlett-Packard Model 5971 GC/MS using a (5\%-phenyl)-methylpolysiloxane DB-5 capillary column $(30 \mathrm{~m} \times 0.25 \mathrm{~mm})$ with film thickness $0.1 \mu \mathrm{m}$; carrier gas helium, flow rate $1 \mathrm{~mL} / \mathrm{min}$ with split mode. The injector temperature and detector temperature were $250^{\circ} \mathrm{C}$ and $280^{\circ} \mathrm{C}$, respectively. The column temperature was programmed at $4^{\circ} \mathrm{C} / \mathrm{min}$ from $35^{\circ} \mathrm{C}$ to $180^{\circ} \mathrm{C}$ and then at $10^{\circ} \mathrm{C} / \mathrm{min}$ from $180^{\circ} \mathrm{C}$ to $250^{\circ} \mathrm{C}$. Mass spectra were recorded from $30-450 \mathrm{~m} / \mathrm{z}$. Individual components were identified by matching their $70 \mathrm{eV}$ mass spectra with those of the spectrometer data base using the Wiley L-Built library and two other computer library MS searches using retention indices as a preselection routine (Alencar et al. 1984, 1990) as well as by visual comparison of the fragmentation pattern with those reported in the literature (Stenhagen et al. 1974, Adams 2001).

\section{USED ORGANISMS}

Second-stage juvenile (J2) of the plant parasite root-knot nematode Meloidogyne incognita and instar III larvae of Aedes aegypti.

\section{NEMATICIDAL BIOASSAY}

Egg masses of $M$. incognita obtained from okra roots with aid of a stereomicroscope were maintained in Petri dishes during $24 \mathrm{~h}$ in distilled water for the juveniles eclosion. $50 \mu \mathrm{L}$ portions of water containing approximately 100 juveniles (J2) were transferred to nematological vials to which $1 \mathrm{mg}$ of the oils to be tested was added and $\mathrm{H}_{2} \mathrm{O}$ :DMSO $2 \%$ solution was poured to complete $1 \mathrm{~mL}$. The nematological vials were kept on a hood at $28^{\circ} \mathrm{C}$. The inactive nematodes counting were performed at every $24 \mathrm{~h}$ for $72 \mathrm{~h}$. After the last counting the inactive juveniles were maintained in distilled water for $24 \mathrm{~h}$ to observe their revival. Four repetitions for each treatment were performed using water and $\mathrm{H}_{2} \mathrm{O}$ :DMSO $2 \%$ solution as control. Table II shows the nematicidal effect for the essential oils from aerial parts of P. apodocephala and P. oligocephala. In Table II the survival figures mean the number of juveniles showing motionless that recovered motility after maintained $24 \mathrm{~h}$ in fresh water. 
TABLE I

Volatile components identified in the essential oils from aerial parts of $P$. apodocephala (oils I and I') and P. oligocephala (oils II and II').

\begin{tabular}{c|c|c|c|c|c}
\hline \multirow{2}{*}{ Compounds $^{\mathrm{a}}$} & \multicolumn{5}{|c}{ Relative contents (\%) } \\
\cline { 2 - 6 } & $\mathrm{IK}^{\mathrm{b}}$ & oil I $^{\mathrm{c}}$ & oil I' $^{\mathrm{d}}$ & oil II $^{\mathrm{c}}$ & oil II $^{\mathrm{d}}$ \\
\hline$\alpha$-pinene & 940 & 11.4 & 10.7 & - & 0.2 \\
\hline 6-methyl-5-hepten-2-one & 991 & 1.0 & - & - & - \\
\hline myrcene & 993 & - & - & 1.7 & 0.7 \\
\hline$\alpha$-phellandrene & 1007 & - & - & 0.9 & 0.5 \\
\hline limonene & 1034 & 6.7 & 6.9 & - & 1.2 \\
\hline$p$-cymene & 1026 & - & - & 70.9 & 50.3 \\
\hline$\beta$-phellandrene & 1046 & - & - & 2.1 & - \\
\hline nerol & 1221 & - & 0.8 & - & - \\
\hline neral & 1235 & 34.2 & 32.2 & - & - \\
\hline geraniol & 1252 & 1.3 & 3.4 & - & - \\
\hline geranial & 1270 & 44.5 & 42.9 & - & - \\
\hline thymol & 1289 & - & & 24.4 & 44.7 \\
\hline$\beta$-caryophyllene & 1427 & - & 0.6 & - & 0.4 \\
\hline$\alpha$-humulene & 1456 & - & 0.6 & - & - \\
\hline Total identified & & 99.1 & 98.1 & 100.0 & 98.0 \\
\hline
\end{tabular}

${ }^{\mathrm{a}}$ Order of elution on DB-5 capillary column. ${ }^{\mathrm{b}} \mathrm{IK}=$ Kovats retention index in reference to $\mathrm{C}_{8}-\mathrm{C}_{26} n$-alkanes on DB-5 column. ${ }^{\mathrm{c}}$ Samples of $P$. apodocephala and $P$. oligocephala collected in May 2000. ${ }^{\mathrm{d}}$ Samples of $P$. apodocephala and $P$. oligocephala collected in June 2003.

\section{TABLE II}

Nematicidal activity $(\%)$ of the essential oils from aerial parts of $P$. apodocephala (oil I and I') and P. oligocephala (oil II and II') expressed as the average of four repetitions for each treatment.

\begin{tabular}{c|c|c|c|c|c|c}
\hline \multirow{2}{*}{ Hours } & \multicolumn{7}{|c}{ Larval mortality (\%) } \\
\cline { 2 - 7 } & oil I & oil I' & oil II & oil II' & Control & $\mathrm{H}_{2} \mathrm{O}$ \\
\hline 24 & 90 & 81 & 96 & 92 & 0 & 0 \\
\hline 48 & 92 & 90 & 100 & 97 & 2 & 4 \\
\hline 72 & 94 & 92 & 100 & 98 & 6 & 9 \\
\hline Survival* & 0 & 0 & 0 & 0 & 6 & 8 \\
\hline
\end{tabular}

*Number of motionless juveniles that recovered motility.

\section{LARVICIDAL BIOASSAY}

Portions of essential oils ( 5 to $500 \mu \mathrm{g} / \mathrm{mL}$ ) were placed in a beaker $(50 \mathrm{~mL})$ and dissolved in $\mathrm{H}_{2} \mathrm{O}$ :DMSO (98.5:1.5). 50 instar III larvae of A. aegypti were delivered to each beaker. After 24 hours, at room temperature, the number of dead larvae was counted and the lethal percentage calculated. A control using DMSO and water was carried out in parallel. For each sample, three independent experiments were run. The bioassays were performed at Laboratório de Entomologia, Núcleo de Endemias da Secretaria de Saúde do Estado do Ceará, Brazil.

\section{RESULTS AND DISCUSSION}

Table I shows the identified constituents and their percentage composition, as well as their Kovats Indices (KI) 
values listed in order of elution from a DB-5 capillary column. The chemical composition of the essential oils from both species, P. apodocephala and P. oligocephala, were essentially constituted by monoterpenes, but as can be seen from Table I, the essential oil of each species has a characteristic chemical composition, either qualitative or quantitative, that has been maintained steady independent of the time of extraction. The main compounds of the oil of P. apodocephala, in order of their abundance, were: geranial (42.9-44.5\%) and neral (32.2-34.2\%) followed by $\alpha$-pinene (10.7-11.4\%) and limonene (6.7$6.9 \%)$. On the other hand, the most prevalent compounds detected in the oils of $P$. oligocephala were $p$-cymene (50.3-70.9\%) and thymol (24.4-44.7\%).

The nematicidal and larvicidal potential of the oils from both species were evaluated against the nematode M. incognita and the A. aegypti larvae. The results of the bioassays are summarized in Tables II and III. Since all oils from both plants exhibited similar and significant activities in the bioassays and the oils have very different chemical composition this make evident the unspecific susceptibility of the tested organisms. Several papers recently published have dealed with biological activities of essential oils. Citral (geranial + neral) rich oils presented antifungal activity (Wang et al. 2005, Pattnaik et al. 1997, Belletti et al. 2004) while thymol rich oils presented, antibacterial, antifungal and larvicidal activities (Singh et al. 2004, Shin and Kim 2004, Tepe et al. 2004, Goren et al. 2003, Carvalho et al. 2003). Interestingly, $p$-cymene in particular, and other monoterpenoids such as $\alpha$ - and $\beta$-pinene are also present as the major components in all those biologically active oils. Despite the two-fold higher concentration of thymol in oil II' the activity of this oil is still similar to the one of oil II. On the other hand, the figures are inverted in the case of $p$-cymene concentrations. If at a lower concentration of $p$-cymene oil II' still showed a slightly improved activity this maybe means that $p$-cymene contributes more for the activity than thymol, once the total concentration of both components (95.3\% and 95.0\%, for oil II and II', respectively) is maintained steady. It is also worthy of notice the higher toxicity of oils II and II' relative to oils I and I' in both assays.

The steady chemical constitution pattern of the oils, associated to their nematicidal and larvicidal properties,
TABLE III

Larvicidal activity of the essential oils from leaves of P. apodocephala (oil I') and P. oligocephala (oil II').

\begin{tabular}{c|c|c}
\hline \multirow{2}{*}{ Conc. $(\mu \mathrm{g} / \mathrm{mL})$} & \multicolumn{2}{|c}{ Larval mortality $(\%)$} \\
\cline { 2 - 3 } & oil I' & oil $\mathrm{II}^{\prime}$ \\
\hline 500 & 96 & 100 \\
\hline 250 & 62 & 100 \\
\hline 100 & 22 & 100 \\
\hline 50 & 3 & 60 \\
\hline 25 & $\mathrm{Nt}$ & 17 \\
\hline
\end{tabular}

$\mathrm{nt}=$ not tested.

could be relevant points to be considered to the possible economical potential of the oils from both species.

\section{ACKNOWLEDGMENTS}

The authors are grateful for the financial support provided by the Brazilian Agencies Conselho Nacional de Desenvolvimento Científico e Tecnológico (CNPq), Coordenação de Aperfeiçoamento de Pessoal de Nível Superior (CAPES), Fundação Cearense de Apoio ao Desenvolvimento Científico e Tecnológico (FUNCAP), Programa de Apoio a Núcleos de Excelência (PRONEX) and Financiadora de Estudos e Projetos (FINEP). Special thanks to Mrs. Olga Ramos (LPN/UFC) and João Carlos da Costa Assunção (DQOI/UFC) for recording the GC-MS spectra.

\section{RESUMO}

A composição química dos óleos essenciais das partes aéreas de Pectis apodocephala e Pectis oligocephala foi analisada por CG-EM. Os óleos essenciais destas espécies foram predominantemente constituídos por monoterpenos. Geranial (42,9$44,5 \%)$, neral $(32,2-34,2 \%)$ e $\alpha$-pineno $(10,7-11,4 \%)$ foram os constituintes majoritários no óleo de $P$. apodocephala, enquanto $p$-cimeno $(50,3-70,9 \%)$ e timol $(24,4-44,7 \%)$, foram os compostos prevalentes no óleo de P. oligocephala. Ambos os óleos foram testados contra o nematóide Meloidogyne incognita e larvas do mosquito Aedes aegypti no terceiro estágio. Os resultados obtidos mostraram que os óleos exibem significante atividade e podem, portanto, ser considerados como potenciais agentes nematicida e larvicida naturais.

Palavras-chave: Pectis apodocephala, Pectis oligocephala, óleo essencial, atividade nematicida, atividade larvicida. 


\section{REFERENCES}

ADAMS RP. 2001. Identification of Essential Oil Components by Gas Chromatography/Quadrupole Mass Spectroscopy. Carol Stream, Illinois, USA: Allured Publishing Corporation, $456 \mathrm{p}$.

Albuquerque MrJR, Souza EB, Mesquita EF, Nunes EP, Cunha AN AND Silveira ER. 2001. Volatile constituents from leaves of Vernonia chalybaea Mart. and Eupatorium ballotaefolium H.B.K. J Essent Oil Res 13: 376-377.

Albuquerque MrJR, Souza EB, Mesquita EF, NunEs EP, CUNHA AN AND Silveira ER. 2003. Volatile constituents of the aerial parts of Pectis apodocephala and Pectis oligocephala. J Essent Oil Res 15: 372-373.

Albuquerque MrJR, Silveira ER, UchoA DEA, Lemos TLG, Souza EB, SANTIago GMP and PesSOA ODL. 2004a. Chemical composition and larvicidal activity of the essential oils from Eupatorium betonicaeforme (D.C.) Baker (Asteraceae). J Agric Food Chem 52: 6708-6711.

Albuquerque MRJR, Souza EB, Lins MUdS, NoGueIRA NAP, Lemos TLG, Silveira ER AND PESSOA ODL. 2004b. Composition and antimicrobial activity of the essential oil from aerial parts of Baccharis trinervis (Lam.) Pers. Arkivoc 6: 59-65.

Alencar JW, Craveiro AA And Matos FJA. 1984. Kovats indices as a preselection routine in mass spectra library search of volatiles. J Nat Prod 47: 890-892.

Alencar JW, Craveiro AA, Matos FJA And MachaDO MIL. 1990. Kovats indices simulation in essential oils analysis. Quim Nova 13: 282-284.

Araújo ECC, Silveira ER, Lima MAS, Neto MA, DE ANDRADE IL, LIMA MAA, SANTIAGO GMP AND MEsquitA ALM. 2003. Insecticidal activity and chemical composition of volatile oils from Hyptis martiusii Benth. J Agric Food Chem 51: 3760-3762.

Belletti N, Ndagijimana M, Sisto C, Guerzoni ME, LANCIOTTI R AND GARDINI F. 2004. Evaluation of the antimicrobial activity of citrus essences on Saccharomyces cerevisiae. J Agric Food Chem 52: 6932-6938.

Carvalho AFU, Melo VMM, Craveiro AA, MachaDO MIL, BANTIM MB AND RABELO EF. 2003. Larvicidal activity of the essential oil from Lippia sidoides Cham. Against Aedes aegypti Linn. Mem Inst Oswaldo Cruz 98: 569-571.

Cheng SH, Chang HT, Chang ST, Tsai KH and Chen WJ. 2003. Bioactivity of selected plant essential oils against the yellow fever mosquito Aedes aegypti larvae.
Biores Technol 89: 99-102.

Craveiro AR, Andrade CHS, Matos FJA, Alencar JW AND MACHADO MIL. 1986. Essential oils from Brazilian Compositae. J Nat Prod 49: 361-363.

Duschatzky CB, Almeida NV AND Bonivardo SL. 2004. Nematicidal activity of the essential oils of several Argentina plants against the root-knot nematode. J Essent Oil Res 16: 626-628.

Goren AC, Bolsel G, Bilsel M, Demir H and KoCABAS EE. 2003. Analysis of essential oil of Coridothymus capitatus (L.) and its antibacterial and antifungal activity. Z Naturforsch C 58c: 687-690.

IACOBEllis NS, CANTORE PL, CAPASSO F AND SENATORE F. 2005. Antibacterial activity of Cuminum cyminum L. and Carum carvi L. essential oils. J Agric Food Chem 53: 57-61.

JAYASINGHE ULB, KUMARIHAMY BMM, BANDARA AGD, Vasquez EA and Kraus W. 2003. Nematicidal activity of some Sri Lankan plants. Nat Prod Res 17: 259-262.

KIM SI, Yi JH, TAK JH AND AHN YJ. 2004. Acaricidal activity of plant essential oils against Dermanyssus gallinae (Acari: Dermanyssidae). Vet Parasitol 120: 297-304.

Pattnaik S, Subramanyam VR, Bapaji M and Kole CR. 1997. Antibacterial and antifungal activity of aromatic constituents of essential oils. Microbios 89: 39-46.

SHIN S AND KIM JH. 2004. Antifungal activities of essential oils from Thymus quinquecostatus and T. magnus. Planta Med 70: 1090-1092.

Singh G, Maurya S, Catalan C and Lampasona MP. 2004. Chemical constituents, antifungal and antioxidative effects of ajwain essential oil and its acetone extract. J Agric Food Chem 52: 3292-3296.

Stenhagen E, Abrahamson S And McLafferty FW. 1974. Registry of Mass Spectral Data Base. Washington DC: Government Printing Office.

Tepe B, Daferera D, SÖlmen M, Polissiou M AND SÖKMEN A. 2004. In vitro antimicrobial and antioxidant activities of the essential oils and various extracts of Thymus eigii M. Zohary et P.H. Davis. J Agric Food Chem 52: 1132-1137.

Venkatachalam MR and Jebanesan A. 2001. Repellent activity of Ferronia alephantum Corr. (Rutaceae) leaf extract against Aedes aegypti (L). Biores Technol 76: 287-288.

WAng SY, Chen PF And Chang ST. 2005. Antifungal activities of essential oils and their constituents from indigenous cinnamon (Cinnamomum osmophloeum) leaves against wood decay fungi. Biores Technol 96: 813-818. 